\title{
Towards optimizing the democratic process
}

Keywords: optimization, democracy, process, election, politics

\section{Opinion}

The basic description of democracy is defined as the political ability that a nation (or a group of individuals) has to decide the general policy of a country through selecting (elections) the leaders, the decision makers and the rules of governing. This approach aims to create a governance of transparency and develop a control methodology over the actions of the responsible. Historical record shows how the democracy evolves from ancient Greece until our modern era through going via different nations and civilisations. Each one of those nations had different traditions and might have adapted the democratic practices according to the local culture and costumes. Therefore, now we can see how different the democratic practices are between nations, although the principal remain the same. This shows how cultural and social specificities of populations should be taken into account when building a model of democracy. This can be seen for instance in the different regulations governing who can be candidate for elections and who cannot among the citizens of the same population. This is also reflected by the differences between countries on how professional competence of decision makers and rulers can or cannot be evaluated by general public or whether there should be a preliminary professional evaluation of candidates in terms of their professional competence.

However, applying such basic principle requires practical tools to make sure the democratic process is correctly followed and its objectives fairly reached. With the concept of "democracy quality", 1,2 several points within the democratic process can be highlighted. First of all, the citizens are asked to elect those they think are the best to rule the country. However, we should ask whether the citizens are fairly informed about and equally influenced by each one of the candidates while they have differences in terms of media (possibly not free $^{3}$ ) access and influence, ${ }^{4}$ campaign finances resources. Indeed, media can either give a higher voice (allow more time on TV for example) for a specific candidate and/or present him as the best while hiding or presenting an inaccurate profile of another candidate. The options to overcome such democratic deficiency could be via legislations that would ensure equal media access and fairly limited financial resources for the campaign to avoid an over influence. Media should also be objective in presenting candidates and parties without taking position for any of them. Most importantly, the electors should focus on the candidates' profiles and their programs rather than the "lights they use during the meetings" which requires to increase awareness probably via a political education that starts at school but does not end with advances ages. Such education would allow electors to finds out whether the political programs are realistic among, generally speaking, developing a political maturity.

Many leading and decisions-making individuals are not elected but are rather named or appointed by persons or institution that might or might not be elected which means that the general public have no impact or how such nomination are made or decided. Herein, there is a need to develop ways leading to determine laws and define processes via which the non-elected individuals can be appointed and most importantly made responsible for their actions via a democracy
Volume 4 Issue 3 - 2020

\author{
Abdelaziz Ghanemi \\ Residence of Mr Brahim Ghanemi and Ms Leila Kara Mostefa, \\ Constantine, Algeria
}

Correspondence: Abdelaziz Ghanemi, No 4I, Rue des Freres Redound, Ouled Rahmoun 25I20, El Khroub, Constantine, Algeria, Email ghanemiabdelziz@hotmail.com

Received: May 16, 2020 | Published: June 12, 2020

approach. To be democratic, such laws and processes have to be passed via a referendum or adopted by an elected parliaments within designed electoral institutions ${ }^{5}$ and autonomous election management bodies. ${ }^{3}$ Some positions cannot be decided by election due to the professional character of the tasks to be completed by the individual such as technical supervisors, medical officials and scientific experts. In this case, the choice should be made via an internal (local) democracy in which only those with enough knowledge about the fields and sufficient implications within the concerned organism.

Whereas, the democracy is, by definition, the application of what the majority wants, protecting the rights of the minorities remains a challenge. Indeed, although many charters have existed at the international, regional and national levels, ${ }^{6-8}$ some legislative systems technically allow adopting laws that might overcome some charters. This issue raises the question of the strength divers legal and juridical documents (charters, constitutions, international conventions, etc) have compared to each other's and whether that have to be "unmodifiable" to protect the political and social stability of the nation or they can be overcame by a government (parliament) that is democratically elected buy the citizens to reflect what the majority general public wants as per the democracy purpose?

The ethical issues are and have always been among some of democratic deficiencies. ${ }^{9-11}$ For instance, a politician can target by his speech a special group and adapt the political program towards such selected speech even that politician does not really believe in the related concept. This leads us to the last point to mention herein, which is whether the elected individuals or parties will in fact respect the promises they made during the electoral campaign and how far will they go in following the electoral program they have presented. Indeed, generally the only "political punishment" they could get for not doing so would be not be elected again. In fact, even the most democratic systems do not have a legal process allowing citizen to "sue" or "judge" those they elected for falling to fulfill their political promises.

It is well understood that either applying democracy itself or the approaches developed to optimize it has to be "adapted" to the local properties of the nation depending on the political system (presidential, parliamentary, kingdom, etc) and the local culture of the society (occidental, oriental, conservative, liberal, etc) and also by including 
related concepts such as policy evaluation. ${ }^{12}$ The concepts introduced within this piece are not only for the politics at the national level but also at the institutional level such as hospital governance ${ }^{13}$ and bank systems. ${ }^{14}$ Importantly, the question of adequacy and structure of our democratic institutions today can also be put for instance because we have the technology which makes it possible for the general public to be approached and asked about any issue on daily basis.

Democracy, as any human-developed approach, is not perfect but is seems to be the best approach human societies were able to develop in order to have a civilized and peaceful way of selecting leaders and rules governing nations and, most importantly, avoid armed conflicts as a "selection process" and a way to determine who rules especially that this affects all the aspects of life including economy. ${ }^{1}$

\section{Potential conflicts of interest}

None (The author declares that there is no conflict of interests).

\section{Acknowledgments}

I am extremely grateful to both Brahim Ghanemi and Leila Kara Mostefa with whom I had rich exchanges and debates about some aspects related to the topics of this publication. In memory of my dearly beloved parents, my father Brahim GHANEMI (1931-2020) and my mother Leila KARA MOSTEFA (1949-2020).

\section{Funding}

None.

\section{References}

1. Christmann P. Economic performance, quality of democracy and satisfaction with democracy. Electoral Studies. 2018;53:79-89.

2. Longstaff H, Secko DM. Assessing the quality of a deliberative democracy mini-public event about advanced biofuel production and development in Canada. Public understanding of science (Bristol, England). 2016;25:252-261.
3. Kerr N, Lührmann A. Public trust in manipulated elections: The role of election administration and media freedom. Electoral Studies. 2017;50:50-67.

4. Schmidbauer H, Rösch A, Stieler F. The 2016 US presidential election and media on Instagram: Who was in the lead? Computers in Human Behavior. 2018;81:148-160.

5. Badas A, Stauffer KE. Voting for women in nonpartisan and partisan elections. Electoral Studies. 2019;57:245-255.

6. Jani HHM, Harun NZ, Mansor M, et al. A Review on the Medina Charter in Response to the Heterogeneous Society in Malaysia. Procedia Environmental Sciences. 2015;28:92-99.

7. Hassan G, Mekki-Berrada A, Rousseau C, et al. Impact of the Charter of Quebec Values on psychological well-being of francophone university students. Transcultural psychiatry. 2016.

8. Mascalzoni D, Dove ES, Rubinstein Y, et al. International Charter of principles for sharing bio-specimens and data. European journal of human genetics: EJHG. 2015;23:721-728.

9. Kim SY, Wall IF, Stanczyk A, et al. Assessing the public's views in research ethics controversies: deliberative democracy and bioethics as natural allies. Journal of empirical research on human research ethics: JERHRE. 2009;4:3-16.

10. Fiester AM. Ill-placed democracy: ethics consultations and the moral status of voting. The Journal of clinical ethics. 2011;22:363-372.

11. Leese M. Holding the Project Accountable: Research Governance, Ethics, and Democracy. Science and engineering ethics. 2017;23:1597-1616.

12. Sager F. Policy evaluation and democracy: Do they fit? Evaluation and program planning. 2018;69:125-129.

13. Definition of Democracy in Emergency Medicine Practice. Annals of emergency medicine. 2016;68:141.

14. Agoraki M-EK, Kouretas GP, Triantopoulos C. Democracy, regulation and competition in emerging banking systems. Economic Modelling. 2019;84:190-202. 